\title{
Effects of Corticosterone and Propylthiouracil on Growth and Hepatic Lipid and Abdominal \\ Fat Deposition in Broiler and Egg-Type Chickens
}

\author{
Yukio AkIBA, Hidenori NagAO and Masaaki HoRIGUCHI* \\ Department of Animal Science, Faculty of Agriculture, \\ Tohoku University, Aoba-ku, Sendai-shi 981
}

(Received March 16, 1992)

\begin{abstract}
Six experiments were conducted to study the effects of corticosterone and/or antithyroid agent (PTU) on growth and lipid deposition in liver and adipose tissue of broiler and egg-type chickens aged 10-32 days. Corticosterone was intramuscularly injected daily at graded dose levels $(300-1200 \mu \mathrm{g} /$ day $/ \mathrm{bird})$ in broiler and egg-type chickens. Chickens starved for 2 days were subjected for 4 days refeeding with corticosterone injection. A silastic tube filled with corticosterone was implanted in egg-type chickens. Corticosterone injection extensively retarded growth rate and increased linearly abdominal fat content as increasing the dose levels. Constant and slow release of corticosterone at a rate of 22 or $43 \mu \mathrm{g} / \mathrm{kg}$ body weight/day from the implanted tube increased abdominal fat content with no growth retardation. PTU feeding $(0.025 \%$ in diet) elevated liver lipid and abdominal fat contents. Concomitant administration of corticosterone and PTU resulted in marked increases of liver lipid and abdominal fat contents. In terms of abdominal fat deposition, broiler chicks appear more susceptible than egg-type chicks of corticosterone administered. It is, therefore, suggested that an increased rate of corticosterone secretion and hypothyroid state are concerned in the fatness of broiler and egg-type chickens.
\end{abstract}

Anim. Sci. Technol. (Jpn.) 63 (9) : 898-904, 1992

Key words : corticosterone, hypothyroid, PTU, chickens, liver lipid, abdominal fat

Injection of broiler chicks with corticosterone retards growth and increases liver lipid and abdominal fat contents ${ }^{7,8,10,11,16\}}$. AKIBA et al. ${ }^{7)}$ reported that in broiler chickens corticosterone released at a low concentration from silastic tubes implanted under the neck skin significantly increased abdominal fat content with no retardation of growth. In addition, A KIBA et al. ${ }^{6}$ observed a significant correlation between plasma corticosterone concentration and abdominal fat content in broilers. Hence, it is suggested that a higher corticosterone concentration in the plasma is possibly concerned in the excess fat deposition which is frequently found in broiler production. There is, however, little information about what extent corticosterone affects lipid deposition in egg-type growing chicks.

Thyroid status affects hepatic lipid deposition. An administration of antithyroid sub-

Present address : * Cluster Coa Institute of Biology, Miyagino-ku, Sendai-shi 983

Anim. Sci. Technol. (Jpn.) 63 (9) : 898-904 898 
stances induces excessive deposition in livers of immature chicks ${ }^{2,5,12,17}$ whereas thyroactive substances decrease liver lipids ${ }^{12,18}$. These reports led authors to expect that the antithyroid agent increases lipid deposition in the carcass and liver of broiler and egg-type chickens.

The present work was undertaken to study the effect of corticosterone and/or antithyroid agent on growth and lipid deposition in liver and adipose tissue of growing chicks.

\section{Materials and Methods}

Animals and diet: Male broiler chickens of Arbor Acre strain and male White Leghorn chickens of Shaver strain were used in 6 experiments. They were reared in cages under a constant lighting program and temperature $\left(22 \pm 2^{\circ} \mathrm{C}\right.$ ). The experimental diet ${ }^{7)}$ (ME 3105 $\mathrm{kcal} / \mathrm{kg}, \mathrm{CP} 20 \%$ ) mainly consisted of corn and soybean meal and water were provided on free access. At the start of each experiment, the birds were weighed and allocated into the specified groups according to their body weight to equalize the mean body weight in each group.

Experiments 1 and 2: White Leghorn chicks (10 days old, $105 \mathrm{~g}$ in mean body weight) and broiler chicks (18 days old, $375 \mathrm{~g}$ in mean body weight) were allocated into 5 or 6 groups with 8 chicks each. The birds were treated with or without corticosterone at graded dose levels and/or propylthiouracil (PTU, $0.025 \%$ in diet) for 14 days.

Experiment 3: White Leghorn chicks (16 days old, $170 \mathrm{~g}$ in mean body weight) were allocated into 5 groups with 8 birds each. They were injected with or without corticosterone at graded dose levels or implanted with corticosterone-tube for 10 days.

Experiments 4 and 5: Broiler chicks (27 days old, $635 \mathrm{~g}$ in mean body weight) and White Leghorn chicks (32 days old, $273 \mathrm{~g}$ in mean body weight) were fed the diet for 4 days following 2 days starvation in experiments 4 and 5 , respectively. A half of the birds in each group received daily injection of corticosterone during the 4 days feeding period.

Experiment 6: White Leghorn chicks (14 days old, $120 \mathrm{~g}$ in mean body weight) were implanted with tube containing corticosterone and reared for 21 days. Estimated release rates from the tube were 22 and $43 \mu \mathrm{g} / \mathrm{kg}$ body weight/day.

Administration of corticosterone: Corticosterone (Sigma Chemical Company, St. Luis, MO, U.S.A.) was administered through two different ways. For the injection, corticosterone dissolved in $0.2 \mathrm{~m} /$ soybean oil was injected intramuscularly into the pectoral muscle daily on $10 \mathrm{AM}$ throughout the experimental period. For the perparation of corticosterone tube, polymethylsiloxane (Silastic, Dow Chemical Corp., Midland, MI, U.S.A.) and Silastic Medical Adhersive Silicone Type A were used by the methods of SMrTH et al. ${ }^{18)}$ and Akiba et al. 4) Different length of corticosterone tubes were implanted under the neck skin to ensure the constant release as being described by AкiBa et al. ${ }^{7)}$ The release rates of corticosterone from implanted tubing were estimated based on the report of KINCL et al. ${ }^{14)}$

Analytical procedure: At the end of each experiment, the birds were killed by cervical dislocation, livers and abdominal fat pads were removed and weighed. Lipid in the liver was extracted by the method of FOLCH et al. ${ }^{13)}$ and quantified by gravimetry. The data were analyzed using the General Linear Model Procedure of STATISTICAL ANALYsis SYSTEM ${ }^{20)}$ with the Duncan separation of means option.

\section{Results}

Experiments 1 and 2: Corticosterone (1200 $\mu \mathrm{g} /$ day) injection and PTU feeding significantly reduced body weight gains but did not affect food intake (Table 1). PTU feeding increased both liver weight and abdominal fat content, whereas corticosterone injection at $1200 \mu \mathrm{g} /$ day increased liver lipid and abdominal fat contents. Implantation of corticosterone tube $(20$ 
Akiba, NaGao and Horiguchi

Table 1. Effects of corticosterone administration and PTU feeding on performance and liver and abdominal fat contents in broiler and egg-type chicks (Experiments 1, 2 and 3 )

\begin{tabular}{|c|c|c|c|c|c|c|}
\hline \multicolumn{2}{|c|}{ Treatment } & \multirow{2}{*}{$\begin{array}{c}\text { Body weight } \\
\text { gain } \\
\text { (g) }\end{array}$} & \multirow{2}{*}{$\begin{array}{c}\text { Food } \\
\text { intake } \\
\text { (g) }\end{array}$} & \multirow{2}{*}{$\begin{array}{l}\text { Liver } \\
\text { weight } \\
(\mathrm{g} / 100 \mathrm{~g} \mathrm{BW})\end{array}$} & \multirow{2}{*}{$\begin{array}{l}\text { Liver lipid } \\
\text { content } \\
\text { (\% wet weight) }\end{array}$} & \multirow{2}{*}{$\begin{array}{l}\text { Abdominal } \\
\text { fat content } \\
(\mathrm{g} / 100 \mathrm{~g} \mathrm{BW})\end{array}$} \\
\hline $\begin{array}{l}\text { Corticosterone } \\
\text { ( } \mu \mathrm{g} / \mathrm{day})\end{array}$ & $\underset{\text { (\%O diet) }}{\text { PTU }}$ & & & & & \\
\hline \multicolumn{7}{|c|}{ Experiment $1^{1}$ (White Leghorn male chicks) } \\
\hline 0 & 0 & $242 \pm 10^{a 6}$ & 377 & $3.4 \pm 0.2^{b}$ & $4.7 \pm 0.4^{b c}$ & $0.34 \pm 0.09^{d}$ \\
\hline $600^{5}$ & 0 & $233 \pm 20^{a}$ & 377 & $3.3 \pm 0.2^{b}$ & $4.3 \pm 0.1^{c}$ & $0.64 \pm 0.24^{c}$ \\
\hline 1200 & 0 & $190 \pm 12^{b}$ & 370 & $3.7 \pm 0.2^{b}$ & $4.9 \pm 0.3^{b}$ & $1.00 \pm 0.15^{b}$ \\
\hline 600 & 0.025 & $191 \pm 8^{b}$ & 363 & $6.2 \pm 0.3^{\mathrm{a}}$ & $5.5 \pm 0.4^{\mathrm{a}}$ & $2.20 \pm 0.10^{\circ}$ \\
\hline 1200 & 0.025 & $185 \pm 15^{b}$ & 363 & $5.7 \pm 0.5^{\mathrm{a}}$ & $5.4 \pm 0.4^{\mathrm{a}}$ & $2.24 \pm 0.36^{\mathrm{a}}$ \\
\hline \multicolumn{7}{|c|}{ Experiment $2^{2}$ (Broiler male chicks) } \\
\hline 0 & 0 & $545 \pm 38^{a 6}$ & \multicolumn{2}{|c|}{$1102 \pm 22^{\mathrm{a}} 2.2 \pm 0.3^{\mathrm{b}}$} & $4.4 \pm 0.3^{b}$ & $0.60 \pm 0.28^{c}$ \\
\hline $20^{4}$ & 0 & $554 \pm 19^{a}$ & \multicolumn{2}{|c|}{$1085 \pm 12^{\mathrm{ab}} 2.3 \pm 0.3^{\mathrm{b}}$} & $4.6 \pm 0.3^{b}$ & $1.00 \pm 0.38^{\mathrm{bc}}$ \\
\hline $600^{5}$ & 0 & $499 \pm 14^{b}$ & \multicolumn{2}{|c|}{$1092 \pm 10^{\mathrm{ab}} 2.4 \pm 0.1^{\mathrm{b}}$} & $5.4 \pm 0.3^{\mathrm{a}}$ & $1.47 \pm 0.50^{\circ}$ \\
\hline 0 & 0.025 & $478 \pm 38^{b}$ & \multicolumn{2}{|c|}{$1084 \pm 8^{a b} 5.0 \pm 0.5^{a}$} & $4.7 \pm 0.5^{b}$ & $1.75 \pm 0.73^{b}$ \\
\hline $20^{4}$ & 0.025 & $491 \pm 14^{b}$ & \multicolumn{2}{|c|}{$1093 \pm 10^{a b} 5.5 \pm 0.5^{a}$} & $4.5 \pm 0.1^{b}$ & $1.89 \pm 0.42^{b}$ \\
\hline 600 & 0.025 & $423 \pm 19^{c}$ & \multicolumn{2}{|c|}{$1064 \pm 29^{\mathrm{b}} 4.9 \pm 0.7^{\mathrm{a}}$} & $5.4 \pm 0.4^{\mathrm{a}}$ & $2.83 \pm 0.44^{\mathrm{a}}$ \\
\hline \multicolumn{7}{|c|}{ Experiment $3^{3}$ (White Leghorn male chicks) } \\
\hline 0 & 0 & $94 \pm 4^{b 0}$ & 289 & $3.1 \pm 0.1^{\mathrm{a}}$ & $4.4 \pm 0.4^{b}$ & $0.34 \pm 0.09^{c}$ \\
\hline $12.4^{4}$ & 0 & $110 \pm 7^{a}$ & 313 & $3.3 \pm 0.5^{\mathrm{a}}$ & $4.5 \pm 0.4^{b}$ & $0.64 \pm 0.24^{b}$ \\
\hline $300^{5}$ & 0 & $92 \pm 7^{b}$ & 284 & $3.1 \pm 0.2^{\mathrm{a}}$ & $4.5 \pm 0.3^{b}$ & $0.55 \pm 0.08^{c}$ \\
\hline 600 & 0 & $84 \pm 10^{b}$ & 297 & $3.1 \pm 0.2^{\mathrm{a}}$ & $4.5 \pm 0.5^{b}$ & $0.65 \pm 0.14^{\mathrm{ab}}$ \\
\hline 1200 & 0 & $78 \pm 8^{b}$ & 267 & $3.2 \pm 0.3^{\mathrm{a}}$ & $5.5 \pm 0.8^{a}$ & $0.94 \pm 0.39^{\mathrm{a}}$ \\
\hline
\end{tabular}

${ }^{1}$ White Leghorn male chicks (10 days old, $105 \mathrm{~g}$ in mean body weight) were treated with corticosterone and/or PTU for 14 days.

${ }^{2}$ Broiler male chicks (18 days old, $375 \mathrm{~g}$ in mean body weight) were treated with corticosterone and/or PTU for 14 days.

${ }^{3}$ White Leghorn male chicks ( 16 days old, $170 \mathrm{~g}$ in mean body weight) were treated with corticosterone for 10 days.

${ }^{4}$ Silastic tube filled with corticosterone was implanted under the neck skin.

${ }^{5}$ Corticosterone dissolved in soybean oil was injected daily into the pectoral muscle.

${ }^{6}$ Mean $\pm S D$ with 8 observations in Experiments 1 and 3 . Mean $\pm S D$ with 5 observations with 3 chicks each in Experiment 2. Means with different superscript letters in columns are significantly different $(P<0.05)$.

$\mu \mathrm{g} /$ day as the release rate) tended to increase abdominal fat content with no retardation in body weight gain in broiler chicks. Concomitant administration of corticosterone and PTU resulted in the marked increase in abdominal fat content in both experiments.

Experiment 3: Injecting corticosterone daily at the rate over $600 \mu \mathrm{g} /$ day tended to reduce body weight gains, but the injection at $300 \mu \mathrm{g} /$ day and tube implants did not affect those (Table 1). There were no significant changes in liver weight and liver lipid content except an increase of liver lipid content in chicks received corticosterone at $1200 \mu \mathrm{g} /$ day. Abdominal fat content increased linearly as an increase of corticosterone doses. Abdominal fat content in chicks implanted with corticosterone-tube (20 $\mu \mathrm{g} /$ day) was almost comparable with that in chicks injected at the level of $600 \mu \mathrm{g} /$ day.

Experiments 4 and 5: Corticosterone injection tended to increase liver weight, liver lipid content and abdominal fat content in starved- 
Table 2. Effects of corticosterone administration on performance and liver lipid and abdominal fat contents in starved and refed chicks (Experiments 4 and 5)

\begin{tabular}{|c|c|c|c|c|c|}
\hline Treatment & \multirow{2}{*}{$\begin{array}{c}\text { Body weight } \\
\text { (g) }\end{array}$} & \multirow{2}{*}{$\begin{array}{l}\text { Food } \\
\text { intake } \\
\text { (g) }\end{array}$} & \multirow{2}{*}{$\begin{array}{l}\text { Liver } \\
\text { weight } \\
(\mathrm{g} / 100 \mathrm{~g} \mathrm{BW})\end{array}$} & \multirow{2}{*}{$\begin{array}{c}\begin{array}{c}\text { Liver lipid } \\
\text { content }\end{array} \\
\text { (\%) wet weight) }\end{array}$} & \multirow{2}{*}{$\begin{array}{l}\text { Abdominal fat } \\
\text { content } \\
(\mathrm{g} / 100 \mathrm{~g} \mathrm{BW})\end{array}$} \\
\hline $\begin{array}{c}\text { Corticosterone } \\
(\mu \mathrm{g} / \mathrm{kg} \mathrm{BW} / \mathrm{day})\end{array}$ & & & & & \\
\hline \multicolumn{6}{|c|}{ Experiment $4^{1}$ (Broiler male chicks) } \\
\hline 0 & $959 \pm 33^{\text {a4 }}$ & 415 & $2.8 \pm 0.2^{b}$ & $4.9 \pm 0.5^{a}$ & $0.90 \pm 0.23^{b}$ \\
\hline 940 & $906 \pm 56^{a}$ & 453 & $3.2 \pm 0.1^{2}$ & $5.4 \pm 0.6^{a}$ & $1.32 \pm 0.23^{\mathrm{a}}$ \\
\hline \multicolumn{6}{|c|}{ Experiment $5^{2}$ (White Leghorn male chicks) } \\
\hline 0 & $391 \pm 16^{\mathrm{a}}$ & 190 & $3.2 \pm 0.2^{\mathrm{a}}$ & $4.9 \pm 0.2^{\mathrm{a}}$ & $0.48 \pm 0.09^{\mathrm{a}}$ \\
\hline 930 & $379 \pm 14^{a}$ & 197 & $3.6 \pm 0.3^{a}$ & $5.2 \pm 0.3^{\mathrm{a}}$ & $0.55 \pm 0.18^{\mathrm{a}}$ \\
\hline
\end{tabular}

${ }^{1}$ Broiler male chicks (27 days old, $635 \mathrm{~g}$ in mean body weight) were fed the diet for 4 days following 2 days starvation.

${ }^{2}$ White Leghorn male chicks ( 32 days old, $273 \mathrm{~g}$ in mean body weight) were fed the diet for 4 days following 2 days starvation.

${ }^{3}$ Corticosterone dissolved in soybean oil was injected daily into the pectoral muscle during 4 days refeeding period.

${ }^{4}$ Mean \pm SD with 5 observations with 2 chicks each. Means with different superscript letters in columns are significantly different $(P<0.05)$.

Table 3. Effects of corticosterone-tube implantation on performance and liver lipid and abdominal fat contents in egg-type chicks ${ }^{1}$ (Experiment 6)

\begin{tabular}{|c|c|c|c|c|c|}
\hline Treatment & Body weight & $\begin{array}{c}\text { Food } \\
\text { intake }\end{array}$ & $\begin{array}{r}\text { Liver } \\
\text { weight }\end{array}$ & $\begin{array}{l}\text { Liver lipid } \\
\text { content }\end{array}$ & $\begin{array}{l}\text { Abdominal fat } \\
\text { content }\end{array}$ \\
\hline $\begin{array}{l}\text { Corticosterone } \\
(\mu \mathrm{g} / \mathrm{kg} \mathrm{BW} / \text { day })\end{array}$ & (g) & (g) & $(\mathrm{g} / 100 \mathrm{~g} B W)$ & (\% wet weight) & $(\mathrm{g} / 100 \mathrm{~g} \mathrm{BW})$ \\
\hline 0 & $280 \pm 8^{a}$ & 642 & $3.5 \pm 0.2^{a}$ & $4.3 \pm 0.4^{a}$ & $0.45 \pm 0.16^{b}$ \\
\hline 22 & $281 \pm 21^{a}$ & 712 & $3.5 \pm 0.2^{\mathrm{a}}$ & $4.3 \pm 0.3^{a}$ & $0.64 \pm 0.24^{\mathrm{ab}}$ \\
\hline 43 & $281 \pm 22^{a}$ & 723 & $3.5 \pm 0.2^{\mathrm{a}}$ & $4.3 \pm 0.4^{a}$ & $0.66 \pm 0.12^{a}$ \\
\hline
\end{tabular}

${ }^{1}$ White Leghorn male chicks (14 days old, $120 \mathrm{~g}$ in mean body weight) were implanted with silastic tube filled with corticosterone and reared for 21 days.

${ }^{2}$ Mean $\pm S D$ with 8 observations. Means with different superscript letters in columns are signifcantly different $(\mathrm{P}<0.05)$.

refed broiler and egg-type chickens, though the significant increase was evident in the abdominal fat content of broiler chickens (Table 2).

Experiment 6: Corticosterone released at $43 \mu \mathrm{g} /$ day from implanted tubes significantly increased abdominal fat content whereas it affected neither body weight gain, food intake, liver weight and liver lipid content (Table 3). Similar trend was demonstrated in chicks implanted corticosterone ( $22 \mu \mathrm{g} / \mathrm{day})$.

\section{Discussion}

It has been documented that injecting cortico- sterone reduces body weight gain and increases lipid deposition in chicks ${ }^{3,7-11}$. The present data show a growth retardation and lipid deposition in the abdominal area by injection of corticosterone in both broiler and egg-type chickens, complementing the previous studies. Furthermore, in experiment 2 we examined the effects of corticosterone when chicks accompanied much lipid deposition and increased lipogenesis. Refeeding for several days fol lowing starvation induces overeating and increased lipid deposition ${ }^{4,15)}$. Our data demonstrate that corticosterone injection accelerates 


\section{AKIBA, NAGAO and HORIGUCHI}

moreover the lipid deposition which was induced by the refeeding following starvation.

Abdominal fat content was increased by daily injection of $600 \mu \mathrm{g}$ corticosterone to approximately 3 times the content in chicks received no corticosterone in both broiler and egg-type chickens (experiments 1 and 2). Considering the dose level of corticosterone per unit body weight, the dose level injected in egg-type chickens was 3 times higher than that in broiler chickens because body weights of the egg-type's were almost one-third those of the broilers. The significant increase of abdominal fat content in the starved-refed chickens was only evident in broiler chicks, but not in egg-type chickens, even when they were injected with the same dose of corticosterone in experiments 4 and 5 . In addition, no significant increase of liver lipid content by injecting $600 \mu \mathrm{g}$ corticosterone was observed in egg-type chickens, despite they received 3 times higher corticosterone than broiler chickens in terms of unit body weight basis. Taken together, it appears that in terms of lipid deposition eggtype chickens are less susceptible to corticosterone injected intramuscularly in comparison with broiler chickens. It is, however, inappropriate to rule out the possibility that the differences in susceptibility to corticosterone might be, in part, due to differences in ages of chickens used.

Implanting tubes ensures a constant and slow release of hormones ${ }^{14}$. The estimated release rates $(12.4 \mu \mathrm{g}-43 \mu \mathrm{g} / \mathrm{kg}$ body weight/day) of corticosterone from tubes are far below the pharmacological level and within almost physiological level as being discussed in our previous paper. This is supported by the evidence that the growth rate was not depressed by the implantation of tube filled with corticosterone, while body weight gain was reduced by the daily injection in the present experiment. In line with our previous experiment using broiler chickens, this study shows that implanting tube to ensure a slow release of cortico- sterone significantly increased abdominal fat deposition in egg-type chickens (experiment 6). The degree of increase in abdominal fat content by corticosterone tube $(12.4 \mu \mathrm{g} / \mathrm{day}$ as the release rate) was almost comparable with that found in egg type chickens injected with $600 \mu \mathrm{g}$ corticosterone (experiment 3 ), being in line with our previous report ${ }^{7)}$ and emphasizing that tube implantation is an effective mean to increase fatness in chickens with no growth retardation.

The corticosterone tube (22 and $43 \mu \mathrm{g} / \mathrm{kg}$ body weight/day as the release rates) elevated abdominal fat content to 1.5 times that in chicks with no corticosterone in the egg-type chickens, whereas in the broiler chickens corticosterone tube $(12.4 \mu \mathrm{g} / \mathrm{kg}$ body weight $/$ day $)$ elevated the abdominal fat up to 1.9 times of chicks with no corticosterone (experiments 3 and 6). Previously, we showed that in broiler chicks implanting corticosterone $(53 \mu \mathrm{g} / \mathrm{kg}$ body weight/day as the release rate) increased abdominal fat content to 2 times of the control $^{7)}$. Thus, in terms of carcass fat deposition broiler chickens are more susceptible than egg-type chickens of corticosterone administered at physiologically low level, although it is unclear whether the reason is ascribed to the difference in plasma corticosterome concentrations and/or the difference in responsiveness of the tissues to exogenous corticosterone. This is coincident with the findings, as being stated above, that broiler chickens respond more susceptively to corticosterone injected and thereby accumulates carcass fats when comparcd to egg-type chickens. This might be a further reflection of findings that broiler chickens accompanies with much deposition of carcass fat in the modern broiler production. Akiba et al. ${ }^{6)}$ demonstrated that a higher corticosterone concentration in plasma is a causative factor promoting excess fat deposition in broilers.

It has been shown in immature egg-type chickens that an administration of PTU induc- 


\section{Corticosterone and Lipid Deposition}

ed hypothyroidism ${ }^{1 /}$ and thereby stimulating lipid deposition in liver ${ }^{2,17}$. In the present study, however, PTU feeding at a level of 0.025 $\%$ had no influence on liver lipid content, while PTU increased the liver weight in broiler chickens (experiments 1 and 2). Obviously shown in the present experiment is that PTU feeding at a low dose level increased extensively abdominal fat deposition in both broiler and egg-type chickens. It is, therefore, suggested that hypothyroid state is concerned, at a certain extent, in the excess fat deposition in chickens.

Since body weight gains were reduced by PTU but not by corticosterone tube, it seems likely that the properties of abdominal fat deposition induced by PTU is not comparable with those induced by the corticosterone implantation. A concomitant administration of PTU and corticosterone markedly increased liver lipid and abdominal fat contents as being shown in Table 1. These effects appear rather additive than synergistic. AKIBA et al. ${ }^{23}$ observed that liver lipid contents were elevated by synergistic actions of PTU and estrogen. Accordingly, it would possibly be better to speculate that mechanism by which corticosterone increases carcass lipid deposition in chickens is not homologous with the mechanism by which estrogen does.

\section{References}

1) Akiba, Y. and T.Matsumoto, Effects of graded doses of goitrin, a goitrogen in rapeseed, on synthesis and release of thyroid hormone in chicks. Jpn. J. Zootech. Sci., 48: 757-765. 1977.

2) Ariba, Y., K. Takahashi, A. Matsuda and T. Matsumoto, Synergism of antithyroid agent and estrogen in the induction of experimental fatty livers in growing chicks. Jpn. Poult. Sci., 19 : 238-244. 1982.

3) AктвA, Y., L.S. JENSEN and M.S. LILbURN, Effect of estrogen implants on hepatic lipid deposition in chicks fed different isonitrogenous and isocaloric diets. J. Nutrition 112: 189-196. 1982.
4) Akiba, Y., L.S. Jensen and C.X. MendonCA, Jr., Laboratory model with chicks for assay of nutritional factors affecting hepatic lipid accumulation in laying hens. Poultry Sci., 62 : 143-151. 1983.

5) Akiba, Y., K. Takahashi, M. Kimura, S.-I. Hirama and T. Matsumoto, The influence of environmental temperature, thyroid status and a synthetic oestrogen on the induction of fatty livers in chicks. Br. Poult. Sci., 24 : 71-80. 1983.

6) Akiba, Y., H. Miura and M. Horiguchi, Lipid accumulation and lipid metabolism in liver and adipose tissue and plasma corticosterone concentration of broiler chicks fed different protein sources or NKK-100. Jpn. Poult. Sci., $24: 220-229$. 1987.

7) Akiba, Y., H. Nagao and M. Horigucht, Effects of corticosterone injected at graded dose levels and implanted with tube at low levels on growth and hepatic lipid and abdominal fat deposition in broiler chickens. Jpn. Poult. Sci., In press. 1992.

8) BARTOV, I., L.S. JENSEN and J.R. VELTMANN, Jr., Effect of corticosterone and prolactin on fattening in broiler chicks. Poultry Sci., 59 : 1328-1334. 1980.

9) Bartov, I., L.S. Jensen and J.R. VeltMANN, Jr., Effect of dietary protein and fat levels on fattening of corticosterone-injected broiler chicks. Poultry Sci., 59: 19641972. 1980.

10) Bellamy, D. and R.A. Leonard, Effect of cortisol on the growth of chicks. Gen. Comp. Endocr., 5 : 402-410. 1965.

11) Dulin, W.E., Effect of corticosterone, cortisone and hydrocortisone on fat metabolism in the chick. Proc. Soc. Exp. Biol. Med., 92 : 253-255. 1956.

12) Evans, J.D., N.O. Buryk, P.J. Midnlfton and H.G. ScHwarTs, Effect of thyroid powder or propylthiouracil on chick liver and plasma lipids. Endocrinology, 70 : 465-470. 1962.

13) Folch, J., M. Lees and G.H. Sloan STANLEY, A simple method for the isolation and purification of total lipids from animal tissues. J. Biol. Chem., 226 : 497509. 1957.

14) Kincl, F.A., G. Benagiano and I. Angee, Sustained release hormonal preparations. 1. Diffusion of various steroids through 
polymer membranes. Steroids, 11 : 673-680. 1968.

15) Leveille, G.A., In vivo fatty acid and cholesterol synthesis in fasted and fastedrefed chicks. J. Nutr., $98:$ 367-372. 1969.

16) Nagra, C.L. and R.K. Meyer, Influence of corticosterone on the metabolism of pal. mitate and glucose metabolism in cockerels. Gen. Comp. Endocr., 3: 131-138. 1963.

17) RAHEJA, K.L. and W.G. LinSChEER, Effect of dietary composition on liver glycoger. accumulation and lipid metabolism in the hypothyroid chick (Gallus domesticus).
Comp. Biochem. Physiol., 61 A : 31-34. 1978.

18) Roberson, R.H. and V. Trujillo, The effect of methionine, thiouracil, dienestrol diacetate and thyroprotein on the development and prevention of fatty liver in pullets. Poultry Sci., 54 : 715-721. 1975.

19) Smith, E.R., D.A. Damassa and J.M. DAvidSON, Hormone administration: Peripheral and intracranial implants. Methods Psychobiol., 3 : 259-279. 1977.

20) Statistical Analysis System, SAS User's guide : Statistics (SAS Institute Inc., ed.). Cary, NC, U.S.A. 1982.

\title{
ブロイラーおよび卵用種ヒナの成長と脂肪蓄積に対する コルチコステロンと抗甲状腺物質投与の影響
}

\author{
秋葉征夫・長尾秀則・啒口雅昭 \\ 東北大学農学部，仙台市青葉区 981
}

ブロイラーにおいて血墏中コルチコステロン濃度と腹㬶内脂肪量の間に正の相関関係があること (AKIBA et al., 1987)，そして，コルチコステロン微量投与により脂肪蓄積が增加すること（AKIBA et al. ，1992）が朋ら加にされている.そこで，コルチコステロンを数段階のレベルで注射した場合上 コルチコステロンチューブ埋込みに上り微量投与した場合，そして抗甲状腺物質（PTU）を投与した 場合の成長上脂肪苗皘の変化をブロイラーおよび卵用種七ナを用いて 6 回の試験を行なって検討した. ブロイラーおよび卵用種雄ヒナにコルチコステロン（300-1200 $\mu \mathrm{g} /$ 羽/日）を钵日 14 日間筋肉注射す ると共に，PTU を飼料中に0.05\% 混合して給与する試験区屯設定した。また，両種の七ナを用いて， 2 日間の絶食の後に 4 日間飼料を再給饂し，その間にコルチコステロンを注射する試験を行なった。 ルチコステロンを生理的微量で定常的に投与するために14 日路の卵用種ヒナにコルチコステロンを充 填したSilastic チューブを皮下に埋込み，21 日間の試験を行なった。コルチコステロン注射によりブ ロイラーおよび卵州種ヒナの成長が有意に低下し，肝臟脂質含量上腹内脂肪含量はコルチコステロン投 与レベルの増加に伴って著しく増加した，卵腄ヒナへのコルチコステロンチューブ埋込みによる微量 投与 (22 $\mu \mathrm{g}$ および $43 \mu \mathrm{g} / \mathrm{kg}$ 体重/日) の場合には成長の低下と肝缄脂質含量の增加は認められず, 腹腔内脂肪含量の有意の增加のみが昌られた，絶食一再給臫した卵州種ヒナでもコルチコステロン注射

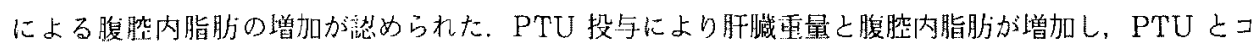
ルチステロン注射の組合わせにより腹内脂䏚は著しく增玑した，以上の結果から，コルチコステロンの

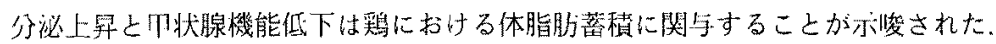

日畜会報, $63(9) ： 898-904,1992$

* 現所属：クラスター・コア生体情報研究所，仙台市宮城野区 983 